\title{
LISTING OF POSITIONS AVAILABLE
}

A. Note to SCHOOLS submitting a placement notice. Your school's notice will appear in only ONE issue of the Newsletter. If you wish to have it listed again, be sure to send another letter each time you wish it to be listed.

We would appreciate it if you would inform us when a position is definitely closed.

\section{POSITIONS AVAILABLE}

LEES-McRAE COLLEGE, Banner Elk, North Carolina 28604

Contact: Mr. Lewis Hall, Academic Dean

Requirements: Person with Master's Degree (some teaching will be required)

Assignment: Language Laboratory Director for Fall 1969

Salary: Dependent upon education and experience, minimum $\$ 6200$ for nine months

PRAIRIE VIEW A AND M COLLEGE, Prairie View, Texas 774-15 Contact: Dr. Alvin J. McNeil, Dean; School of Arts and Sciences Requirements: M.A. preferred

Assignment: Lab Director for September 1969. Must teach at least two classes in French, German or Spanish.

Salary: Depending upon qualifications

Specifics: Thirty position four channel RCA Laboratory; new one hundred position lab proposed for September 1969

MONASH UNIVERSITY, Clayton, Victoria, AUSTRALIA 3168

Contact: Wilga M. Rivers, French Section

Requirements: The appointment could be Lecturer (Assistant Professor) or Senior Lecturer (Associate Professor) level according to the qualifications and experience of the applicant, and would therefore expect the applicant to have completed his Ph.D.

Assignment: General administration and budgeting, distributes work allotment of technical officers, gives advice to uninitiated Language Department, designs tape programs for course practice, trains new personnel, initiates guide research into the new effectiveness of Language Lab Testing 
Salary: Australian salaries are not as high as American salaries but a successful applicant has all travel and removal expenses for himself and family paid to Australia, and has the right of repartriation (travel and removal expenses) after three years if he doesn't want to stay. University housing is provided at a nominal rate until the applicant finds what he wants. Cost of living in Australia would be perhaps $3 / 4$ of American cost of living (e.g. food cheaper, electrical goods and books more expensive.)

Specifics: 84 stations ( 30 audio-active and rest full recording; 4 full-time technical officers (electronics and photographic men, not students)

TOWSON STATE COLLEGE, Baltimore, Maryland 21204

Contact: R. A. Magill, Chairman, Department of Modern Languages.

Requirements: M.A.

Assignment: Part-time laboratory director who can handle a three quarter teaching load in French beside his lab responsibilities

Salary: $\$ 7000$ to $\$ 8000$

Specifics: New installation with thirty-six stations and four simultaneous programs available from the supervisor's console

INDIANA STATE UNIVERSITY, Terre Haute, Indiana 47809

Contact: Dr. Louis L. Curcio, Chairman, Department of Foreign Languages

Requirements: Masters Degrce in a modern foreign language with training and experience in the use and supervision of a language laboratory

Assignment: Language Laboratory Director for June, 1969, and following. One course in appropriate FL or in MFL methodology.

Salary: According to qualifications; competitive

Specifics: Laboratory installation consists of 50 position audio-active-record student area (RCA units), custom console with 6 channels, plus 4 remote; preparation room with telephone type relay racks, three professional tape decks (Viking RP110), two smaller tape decks (Viking 87), AM-FM tuner, Hammarlund HQ $100 A$ short wave receiver, one Bogen turntable, one Rek-o-kut turntable, Harmon mixer, related preamps, amplifiers and patch panel. Sound studio with condenser microphone (Norelco) adjoins preparation room. Director will have both graduate and undergraduate assistants to staff lab. 
UNIVERSITY OF FLORIDA, Gainesville, Florida 32601

Contact: Dr. Irving R. Wershow, Chairman, Selection Committee, Dept. of Foreign Languages.

Requirements: Rank will be assistant professor

Assignment: Language Lab director beginning in the summer or fall of 1969. No teaching required, but experience as a successful teacher is desireable.

Salary: Open to negotiation

Specifics: Foreign Languages have just moved into comfortable quarters in a completely renovated building. A large new language laboratory (dial access equipment) is to be in operation in January. A separate 30-position classroom (with remote-controlled recorders) will also be installed.

STATE UNIVERSITY OF NEW YORK COLLEGE AT CORTLAND, Cortland, New York 13045

Contact: Robert M. Hammond, Chairman, Department of Foreign Languages.

Requirement: At least M.A. degree

Assignment: Teaching one course (3-4 contact credit hour) and approximately 22.25 hours in Language lab and make minor technical repairs. Dub tapes. Teach Spanish: Beginning, Intermediate and Conversation. Ability to speak Spanish, French, German, Russian (at least 3 of these languages) and Linguistic training in Phonology, Morphology (at least) in order to be able to assist the students in the Lab with proper pronunciation and intonation.

Salary: \$8500. (Instructor - Asst. Prof.)

Specifics: 30 booth, dial access (General Electronics, Boston) with 30 remote student-controlled tape decks, plus 14 four-track monaural dial access decks. Console with 6 program sources (2 4-track decks, 1 phono, 1 dial access, 2 auxiliary). Most of the tapes are commercially prepared (dubbed or purchased). Students are required to spend 1 hour in Lab for each course.

THE PENNSYLVANIA STATE UNIVERSITY, 105 Burrowes Building, University Park, Penn. 16802

Contact: Mr. Stanley R. Townsend, Head, Department of German Requirements: $\mathrm{Ph} . \mathrm{D}$. with qualifications for assistant professor in German 
Assignment: Specialist in Teaching Methods, Teach German on the secondary and college levels, take charge of elementary and intermediate German teaching, and supervise instruction by graduate teaching assistants. Applicants should have had experience in modern audio-lingual teaching in the United States, should preferably be native speakers of the language, and be prepared to carry on research in the techniques and technology of foreign language teaching. Teaching load is secondary to supervisory and research responsibilities. This is not a language laboratory director's position, but one for a researcher with teaching and administrative ability who would work in an allied field.

Salary: Appropriate to qualifications of applicant.

LOYOLA COLLEGE, Baltimore, Maryland

Contact: Dr. Morgan H. Pritchett, Chairman, Telephone 301-4352500 , ext. 302.

Requirements: M.A.

Assignment: Language Lab Director

Salary: Open, depending on experience

Specifics: Lab has 36 positions and has been recently installed with a recording room; Director will have regular student assistants to help in operating lab. The lab is used both on a library and "lock-step" basis.

AUBURN UNIVERSITY, Auburn, Alabama

Contact: Prof. J. Hunter Peak

Requirements: Well trained in at least one of the foreign languages and willing to teach one of the beginning or intermediate classes each quarter, four quarters per year.

Assignment: Lab director

Salary: Depending on experience.

Specifics: Lab consists of two rooms with 30 listening-record positions and a console in one room and 20 listening-respond booths in a second room. The tape sources, 64 in number, will be installed in a special room. Eight classrooms will have a speaker installed to enable teacher to supplement his work with a dial access program.

\section{POSITIONS WANTED}

Wanted: Position as head and/or technician of a Language Laboratory of a whole learning center with Dial-Access Information Retrieval. Would prefer public college in Florida. 
Experience: Two years experience dealing with such equipment and applying it to educational problems: A. Assistant Head and Technician B. Acting head and Technician (both at Dean Junior College Franklin, Massachusetts 02038)

C. I am very familiar with Chester Electronics Laboratories:

1. Centralized audio tape playing equipment

2. Tape Decks

3. Student recorders

4. Automatic switching

5. Dial Access

6. Dubbers etc.

7. Video tape outfits

8. Audio-visual aids

D. I have factory training but I am a technician primarily in the sense of being able to apply this technical electronics teaching equipment to problems of education. In this I am helped by training in the Physical Sciences, Education and Psychology, having had considerable course work in each and a great deal of teaching experience in each. My Master's Degree is in Psychology.

Contact: NALLD Publications Center Box 521

Ellis Hall

Ohio University

Athens, Ohio 45701

Wanted: Lab Director Position

Degrees: BA major in letters, Havana, 1945

Dr. of Pedagogy, major in Education, University of Havana, 1950 18 credit-hours at the University of Miami, Coral Gables, Fla. for the validation of Cuban degrees. M.A. in Spanish, West Virginia University, Morgantown, W. Va. 1968

Appointments:

Taught Spanish I and 2 at Americus High School, Americus, Ga., 1964-67. Taught Spanish 101, 102, and 103 at Georgia Southwestern College, 19640. Teaching Intermediate Spanish at West Virginia University as a Graduate Assistant, 1967-68. Spanish Instructor and Director of Language Laboratory, West Virginia University, August, 1968. 15 years of teaching experience in Cuba.

Contact: NALLD Publications Center Box 503

Ellis Hall

Ohio University

Athens, Ohio 45701. 